Article

\title{
Smart City Management in the Context of Electricity Consumption Savings
}

\begin{abstract}
Aleksandra Ptak
Faculty of Management, Czestochowa University of Technology, Armii Krajowej 19B, 42-200 Czestochowa, Poland; aleksandra.ptak@pcz.pl; Tel.: +48-343250489

Abstract: According to one definition, Smart City is an administrative unit that uses data and digital technology to improve the decision-making processes and well-being of its inhabitants. Smart Cities use modern, intelligent technologies to forecast future changes, optimize city functions, gain a better understanding of current conditions, and deliver solutions. To make the city smart, multiple connected sensors, smartphones and other IoT devices are needed. As part of the research conducted at the Technical University in Vienna, six key dimensions (categories) of smart cities have been identified and characterized: Smart Economy, Smart Mobility, Smart Environment, Smart People, Smart Living, and Smart Governance. The aim of the paper is to present the concept of the smart cities, the implemented innovative solutions and the issue of electricity saving in Smart Cities. The theoretical considerations were expanded of the presentation of selected smart city projects in Polish cities. The considerations were also supplemented with the results of research conducted on a group of respondents living in large and very large cities in Poland in order to their awareness of the concept of smart cities, awareness on smart projects implemented in their cities of residence, and the possibility of using intelligent technologies to achieve savings in electricity consumption.
\end{abstract}

check for

updates

Citation: Ptak, A. Smart City

Management in the Context of Electricity Consumption Savings. Energies 2021, 14, 6170.

https://doi.org/10.3390/en14196170

Academic Editors: Dorota Jelonek and Andrzej Sobczak

Received: 14 August 2021

Accepted: 22 September 2021

Published: 27 September 2021

Publisher's Note: MDPI stays neutral with regard to jurisdictional claims in published maps and institutional affiliations.

Copyright: (C) 2021 by the author. Licensee MDPI, Basel, Switzerland. This article is an open access article distributed under the terms and conditions of the Creative Commons Attribution (CC BY) license (https:// creativecommons.org/licenses/by/ $4.0 /)$.
Keywords: smart cities; innovations; information-communitation technologies; electricity

\section{Introduction}

The presented paper deals with the issues of needs, opportunities, benefits, and limitations related to the functioning of cities based on the smart city idea, which is related to management, including saving electricity consumption. The author's approach to the problem resulted directly from the observation of the surrounding reality, as well as the knowledge gained as a result of the conducted literature research. On this basis, the author concluded that ICT technologies, on which the smart city are based, to a large extent, make it possible to reduce energy consumption while not limiting the functionality of the city's areas inherently related to the use of electricity. The implementation of the research process was related to the search and analysis of answers to the following questions:

- What is the smart city idea and what areas of the city does it cover?

- Which areas of the city's functioning are most often associated by the inhabitants with the idea of a smart city?

- How do city dwellers approach the issue of saving electricity use?

- To what extent can the smart city idea contribute to savings in electricity consumption in cities, and what are the possibilities in this regard?

Building Smart City is related to the set of various activities that can be used in many areas. The following are worth mentioning [1]:

- connectivity

- telecommunications

- mobility

- transport

- $\quad$ intelligent public and road lighting 
- video protection

- infrastructure for education and healthcare (which have gained importance in the time of the pandemic)

- $\quad$ tools for public services

- $\quad$ water and waste treatment

- measuring air quality

The six main areas of this idea (Smart Economy, Smart Mobility, Smart Environment, Smart People, Smart Living and Smart Governance) should be treated equally in order for the city to develop in a sustainable manner [2] and actually become an increasingly "smart/intelligent center". Creating the smart city requires the implementation of multidimensional strategies covering all of the above-mentioned planes. In fact, it is about using solutions in the field of the Internet of Things (IoT), Big Data or artificial intelligence tools to make more accurate decisions, which translates into reducing crime, reducing the time needed for commuting, lower $\mathrm{CO}_{2}$ emissions, saving water and electricity, etc. New technologies make it possible to share data in real time (e.g., regarding the location of public transport vehicles), but also allow us to learn about certain behavior patterns and create "tailor-made" solutions, optimize city operations, and generate savings [3].

Smart City derives its intelligence from the combination of ideology and technology as well as the cooperation of people, institutions, and companies. Working together allows us to strive for sustainable development and to achieve better quality of life in the city.

The main goal of the publication is to identify and analyze the awareness of the smart city idea among the inhabitants of modern cities, including the possibility of using the foundations of the idea in order to save electricity consumption.

The adoption of such a goal is related to the author's knowledge of the smart city idea, including the possibilities it gives to improve the functioning of the inhabitants of modern cities. At the same time, the author assumes that the awareness of the smart city idea among the inhabitants of many, including Polish cities, is not at a sufficient level. Residents use the amenities provided by ICT on a daily basis, but are not aware of the systemic possibilities of their use. According to the author, residents use ICT to implement individual ad hoc activities. At the same time, they often express an opinion on the lack of use of ICT in many areas of operation, which, in their opinion, would further improve life. The issue of electricity saving is a problem widely discussed in contemporary literature, including that related to management sciences [4]. It is related to understanding the excessive use of the earth's natural resources, which is reflected in the area of sciences known as sustainable development. According to the author, ICT technologies are used in cities primarily to implement ad hoc amenities for residents. This applies especially to cities from regions with a low level of technological advancement, including those remaining under the influence of the Soviet Union, including Poland, after the Second World War. ICT and the smart city idea offer great opportunities for taking actions aimed at saving electricity consumption. Importantly, without reducing the efficiency of urban areas that are naturally related to energy consumption. This issue is all the more important because, as the research results show, cities are now the largest global communities of people.

The implementation of such a goal is associated with the following research hypotheses:

- Despite widespread use of ICT, the inhabitants of modern cities have limited knowledge about the essence and usefulness of the smart city ideology.

- The idea of a smart city has a positive impact on the issues of electricity consumption savings in modern cities.

\section{Literature Background}

A Smart City is a city that uses technological innovations-most often in the areas of Internet, telecommunications, and energy. It tries to combine them with social innovations based on the participation of citizens. Strong connection of all these areas into a common project creates many facilities in various areas of city life. The most noticeable for both residents and tourists is the fact that they use more public transport, which works so 
efficiently that it allows people to move around the city faster. More people on the subway, buses, and trams, but fewer cars on the roads. Greater smoothness of traffic translates into less traffic jams, which in turn is tangible evidence of efficient management. However, communication is only one of the areas that allows a city to be intelligent. There are other challenges facing agglomerations [5].

With the help of appropriate software, road signs can be checked, and available parking spaces can be dynamically displayed. Connected systems enable remote adjustment of signals in increased traffic. It is also possible to improve road traffic by optimizing signaling sequences.

Smart City technologies help cities save resources by reducing electricity, water, and gas costs. They can automate energy consumption data storage and enable intelligent control of systems to improve energy efficiency. The software platform enables, for example, fully automatic control of lighting, cooling, heating, roller shutters (depending on the weather). Lighting, heating, or cooling optimized this way significantly reduces energy costs. The system can, for example, "learn" and heat the room only during the hours it is normally used, which also helps to reduce energy consumption [6]. Smart technology can also be used to automatically optimize electricity consumption in buildings through efficient control of lighting and elevators. In addition, it can also help to reduce water consumption or help identify leaks in water pipes more efficiently [7].

Smart technology detects movement and increases or decreases the level of illumination depending on its intensity. Such dynamic lighting not only improves safety and mobility in the city, but also reduces electricity costs and contributes to reducing environmental pollution. Motion sensors work with the lighting network, increasing its level when they detect that there are people or vehicles in the certain area. Optical sensors in the smart luminaires detect not just individual cars but also traffic in both directions. They decrease the level of lighting when there is no traffic, which generates significant energy savings. Thermal imaging cameras in combination with visible light cameras in the traffic safety area prevent traffic jams and are used in the process of optical vehicle recognition. Cameras are mounted on extension poles and directed down towards the stop line. Thanks to this, one can check on which lanes there are cars and how many there are. All data then goes to an adaptive control system that modifies the traffic light cycles based on the traffic. Wi-Fi technology is used to monitor the travel time, it allows us to calculate the efficiency of an intersection, traffic route, the pace of travel between points and analyzes the place of the beginning and destination [6]. Energy reduction is also associated with the replacement of traditional sodium light bulbs with LED lighting. The implementation of the intelligent control system that allows power regulation and individual control of the operation of each light point, brings about twice as much in the form of savings in electricity consumption and service costs. Thanks to the constant power supply and access to the data transmission network, the lighthouse automatically becomes the point where one can place additional sensors; the city surveillance camera, hot spot, the additional power point for advertising media, or the electric vehicle charging station [6]. Energy-saving monitors use LED lights which are extremely energy efficient and also very durable. LED backlight gives great energy savings, up to $40 \%$. An energy-saving LED backlight is also installed in modern coffered light advertisements.

Sustainable development can be achieved by Smart Cities through the intelligent control of the city by energy systems or monitoring of environmental conditions. Intelligent sensors are programmed to take real-time air quality measurements, add this information to the database and send alerts when harmful levels increase. Thanks to this support, cities are able to monitor the condition and identify possible sources of pollution in their specific areas. The issue of integrating renewable energy resources cannot be overlooked either. Systems for collecting energy and other resources can make energy systems in municipal networks greener. Thanks to the appropriate system, it is possible to manage, control and optimize devices for acquiring renewable energy (wind farms, solar installations, and hydroelectric plants). The mentioned solar panels located on the roofs provide environmental 
benefits, and managing them from one central system can greatly facilitate the management of dispersed resources [7].

Integrating security systems both in buildings and in public spaces, allowing for more effective monitoring and control, enables cities' IoT. Connected to the Internet surveillance cameras, alarm systems and access control systems can help stop thefts, property damages and other crimes, and find the perpetrators. Cities can also install a combined fire alarm and other warning systems in buildings and public spaces. Cities around the world have experienced the crisis caused by the pandemic [8]. Calls for social distancing, restrictions on movement, closed offices, suspended public transport-these are just some of its manifestations [9]. The implemented solutions facilitate the functioning of residents, in many cases meeting the criterion of building a Smart City. When problems arise, Smart technologies improve security by remotely monitoring and controlling of systems [10].

Smart city technology can also contribute to increasing road safety. Fire alarms or combined lighting and ventilation systems in tunnels can allow remote monitoring and alerting for greater safety. Relevant departments can control lighting systems and street signs remotely. These smart systems help to ensure a smooth flow of traffic, and the likelihood of accidents is additionally reduced by signs to alert drivers to hazards [10]. Safety in cities can also be improved by guaranteeing a reliable energy supply. Smart systems can help manage the power network by minimizing the risk of power failure. Integrated energy infrastructure can generate early warnings of problems and allow more flexible grid control. Thanks to the data provided by intelligent systems and predictive analysis, it is possible to schedule maintenance works on the energy infrastructure in order to ensure optimal functioning of the network.

Electronic medical documentation is one of the main e-health tools, which also include: exchange of medical information, telehealth, and the so-called Personal Health Records. Innovative mobile applications make it possible to build new relationships between patients and medical staff. They are conducive to better personalization of medical care, change modern medicine, constituting the basis of the so-called personalized medicine. Remote diagnostics using personal mobile devices increases the chances of survival in emergency situations. Various types of measures that transmit information about the state of our health to the outside world. An example is contact lenses that measure blood sugar levels on an ongoing basis. This solution allows you to display the sugar level on the smartphone. The expansion of information and communication technologies and consumer e/mHealth tools and services improves the quality of life of all members of society and revolutionizes the healthcare system. Wearable electronics, biosensors, i.e., smart wearable body sensors (SWS), are used primarily in monitoring cardiovascular diseases, diabetes, Parkinson's and Alzheimer's diseases, as well as telerehabilitation [11,12].

Smart Technologies allow for faster implementation of initiatives and undoubtedly can encourage partnership cooperation between public and private entities. Infrastructure investments have traditionally forced local governments to make long-term plans requiring large capital expenditure, but cities were helped to increase their flexibility and respond quickly to changing demand by combining traditional construction with intelligent technological solutions. Cities can introduce smart city solutions one at a time, and then update them when needed. Many smart city initiatives that local governments can implement can provide a positive financial return, which in turn can encourage to fund them by the local governments or private sector entities. Greater private sector involvement in these initiatives can foster creativity and increase adaptability. The document implementing the idea of telemedicine healthcare in a smart city is the "Digital European Agenda" (EAC). It states that the use of technologies enabling the provision of electronic health services in Europe can improve the quality of medical care, reduce treatment costs, and promote independent life, also in non-urban areas. New telemedicine services, such as direct medical consultations on the Internet, better emergency care and the use of portable devices to monitor the health of people with chronic diseases and people with disabilities, potentially give patients freedom of movement [13]. 
Finally, creating the smarter city can make it the technological leader and attract talented people. Smart technologies create jobs, develop smart city projects, install, and maintain smart equipment, and much more. Improving transport can encourage people to participate in the economy as it becomes easier for them to travel for work purposes. Additionally, smart technology can support companies that play a vital role in the urban economy. Rail, air, water, and other transport are just a few examples of the areas where jobs are created and goods flow. Smart City technologies can be used to manage transit traffic, optimize travel routes, and implement preventive maintenance.

\subsection{Development of Smart Cities in the World}

The creation and development of smart cities is closely related to the reality that surrounds us. We have been observing ever faster population growth for a long time. Over 4 billion people were born in the last 50 years [14]. According to UN data, 55\% of the global population now lives in urban areas, and by 2050 this number will increase to $68 \%$. In Poland, according to the statistics of the Central Statistical Office (GUS), city dwellers constitute over $60 \%$ of the total population. The largest cities in terms of population are Warsaw and Kraków (1,758,143 and 766,739 inhabitants, respectively) [15]. The growing population means that cities consume $60-80 \%$ of global energy resources, and their share in greenhouse gas emissions increases every year [16]. That is why cities will need smart solutions to support this growth. Cities that implement intelligent technologies and use intelligent strategies for this purpose can be expected to improve the quality of life of their inhabitants and become global leaders. The transformation into smart cities is already underway in many places around the world. According to research, from 2019 to 2025, the global smart city market will develop with a cumulative annual growth rate of almost $19 \%(18.9 \%)$ and will reach a value of USD 237.6 billion. This estimated growth shows how seriously cities are considering implementing Smart Cities systems. In the coming years, it will be possible to observe the development of many new smart cities and the introduction of innovative solutions [5].

The report "Street Smart. Putting the citizen at the center of smart city initiatives" carried out across 10 countries in April 2020 shows that as many as 3 out of 4 people who happened to use smart city solutions declare greater satisfaction with the standard of living, including air quality. Furthermore, one out of three residents is willing to pay extra for using the benefits of smart cities [17]. According to estimates by Worldwide Smart Cities - in 2020, spending on smart city initiatives amounted to approximately USD 124 billion, which in relation to the previous 12 months means a fairly large increase, by as much as $19 \%$. Intelligent urban and architectural solutions are becoming a trend. A study by Capgemini shows that as much as 60 percent of city residents would like to live in a smart city. It was mostly millennials who showed a great willingness to function in such a space (64 percent), as well as people who earn over USD 80,000. Fifty-six percent of those willing to live in a smart city are people earning less than $\$ 20,000$. In the coming years, global spending on smart city-related goals is to increase even more. According to IDC, it is estimated that they will amount to USD 189.5 billion in 2023 [18]. The Capgemini report shows that city residents want to live in a smart city, believing that it will provide a greater quality of life-not limited only to basic infrastructure needs. Thus, as much as 54 percent of citizens say tech companies would be better able to provide city services than the current government. People also believe that smart solutions will contribute to a more sustainable urban development (58\%), the quality of urban services (57\%) and the quality of life (54\%) will improve [17].

\subsection{Polish Smart Cities_Examples of Smart Projects}

This part of the article presents selected Polish cities and their solutions in the field of smart projects. The selection was made with reference to the research group of the conducted research. One city with over 500,000 inhabitants, one with 300,000 to 500,000 inhabitants and one city with 100,000 to 300,000 inhabitants is presented. 


\subsubsection{Wrocław}

iMPK passenger application allows us, among other things, to track public transport vehicles based on the GPS position, check whether they are going according to the schedule, view a photo of the type of bus that is going us, and download the timetable from a specific stop to the phone. One can see if a given vehicle is late or is driving according to the schedule. There is also a timetable for passengers, along with information about the possibility of transfers [19].

One of the housing estates in Wrocław has an intelligent and economical lighting system. The project was realized by Philips Lighting. Streetlamps have been installed at two heights so that the light goes exactly where it is needed. The Lumimotion system installed in them detects movement or its absence and adjusts the light intensity accordingly. The lighting can be remotely controlled and adjusted to the prevailing weather conditions. LED lighting was used on the estate, which gives significant savings on electricity costs. Rainwater is also used on the estate; it is collected in underground and open reservoirs. Part of the rainwater also supplies the housing estate's water system as the so-called "gray water", used for irrigation or flushing toilets. This way, operating costs are lowered. All buildings in the estate are heated by municipal heat suppliers. Thanks to this, they do not contribute to the formation of smog. Some of the buildings are also equipped with photovoltaic panels [20].

The task of the Virtual Resident Advisor is to improve the search for necessary information on the pages of the Public Information Bulletin in Wrocław. The IT system is prepared for thousands of questions from residents and officials. The solution belongs to the group of the so-called "intelligence customer interaction solutions" and uses the integration of sound and video with artificial intelligence mechanisms. The Virtual Resident Advisor is a chat-based dialogue system that simulates a conversation with a real person, leading the user on the BIP side to the right answer. It is assumed that the Virtual Resident Advisor, in the long term, e.g., reduces the digital exclusion of citizens by significantly facilitating the use of the system, in particular for people who prefer the text channel over the telephone one, reduces the costs of system support-all lines of support will use the common Knowledge Base-from Virtual Advisor, through Contact Center consultants, to clerks, provides many important statistics, increases the user-friendliness of the use of assistance [21].

Project Smart Trip is based on the analysis of transport resources, including roads, parking lots, rental cars, bicycles, trams, and it optimizes the use of these resources. In the advanced version, based on the preferences of the traveler, the tool helps to choose not only the appropriate means of transport and the convenient route, but also minimizes travel costs and facilitate payment. The result of work on the project is, among others, Mobill app [22].

An electric vehicle charging system aims to promote ecological travel by electric car and involves the construction of an infrastructure for charging electric vehicles. The charging network implemented in Wrocław includes 10 terminals for electric vehicles so far.

\subsubsection{Lublin}

The public transport base in Lublin is extremely extensive, and its range covers neighboring communes. Lublin is one of three cities in Poland which, apart from bus connections, has developed the trolleybus network which is an element of a low-emission transport policy. The city also supports electromobility for private means of transport in the form of implementing charging infrastructure for electric vehicles. In addition, the city has a network of electric scooters and scooters, as well as a fleet of city bikes that can be driven along $170 \mathrm{~km}$ of bicycle paths [23].

The comprehensive 3D model of the spatial city, for which Lublin received the prestigious Smart City Award, presents three-dimensional visualizations of urban facilities, the topography of the city, layers of greenery and spatial phenomena. It also allows us to create multi-faceted 3D analyzes along with thematic studies not only for officials but also 
for all city residents. This makes it possible to create various analyzes, e.g., environmental analyzes related to the distribution of noise from the acoustic map in the three-dimensional space, to perform measurements or export data [24].

The concept known as human smart city 3:0 assumes a much more active involvement of residents in the co-decision processes of the city. There has been a civic budget in Lublin for a long time, and in 2017 Lublin was the first city in Poland to introduce a green civic budget [25].

The aim of the EDU Lublin project was to implement an integrated IT system for educational units [26]. The system certainly facilitated the transition to distance learning by students during the covid-19 pandemic in a non-conflict manner.

The aim of the collaborative network set up by the European Institute of Innovation and Technology (EIT) is to use innovation within the "knowledge triangle" of collaboration between research centers, universities, and businesses [27], where cities become living laboratories for testing. Lublin has been a member of the EIT since 2020 and there were already implemented international projects in the field of urban mobility [25].

The Lublin 2030 strategy project is the project in which the city decided to involve the city inhabitants. The participatory nature of the project will allow us to determine the optimal direction of the city's development, which will take into account the needs of both the local government and the residents. The project "Let's come up with Lublin together. We participate in creating a smart strategy Lublin 2030" received an award in the Human Smart Cities competition organized by the Ministry of Investments and Development [28].

The Traffic Management System aims primarily to improve the flow of road traffic through a properly programmed change of lights, as well as to improve road safety. Another example of Smart City projects is Lublin Virtual Library, city telecommunications system, Municipal Data Center and Backup Center, over 250 hotspots, or 230 video surveillance cameras in public space.

\subsubsection{Częstochowa}

The Electronic Czestochowa Resident Card System together with the Local Government Loyalty Program is a kind of communication platform with residents. The economic goal is to support local entrepreneurs who, in the age of globalization, find it harder and harder to compete for clients. As part of the program, residents are rewarded for supporting local businesses, which increases awareness and real support for local business. The CKM holder accumulates points while shopping. After collecting them in an appropriate amount, he can exchange them for a discount voucher when shopping at any program partner. The Municipal Transport Company in Czestochowa joined the CKM program. The company integrates chip cards on which it codes season tickets for trams and buses with CKM cards. More specifically, its chip cards are saved in the CKM system and allow us to collect and exchange points. A resident who has an electronic ticket stored on a chip card can use this card when shopping at any CKM partner and the MPK card is automatically added to the system [29].

Czestochowa city bike is an alternative mean of transport that allows people to move quickly around the city. CRM cyclists have 23 stations and 200 bicycles at their disposal. Stations are equipped with touch screens and the possibility of paying at the terminals with credit and debit cards. A modern bicycle security system (electric locks) guarantees comfortable rentals. The benefits for residents include a large number of bicycles available $24 \mathrm{~h}$ a day/7 days a week. Quick registration and easy operation via the terminal or telephone (bike rental is possible with the mobile application for all available platforms (Android, iOS, Windows Phone). It allows for quick rentals, checking the location of the station and the condition of bikes, as well as access to the user's account. Rental and return is possible at any station, bike stations are present in communication nodes and car-free zones [30].

Traffic light counters are primarily intended to inform drivers, motorcyclists, cyclists, and pedestrians how much time is left for the ride or crossing the street. According to the 
authors of this project, the timer may affect the route and technique of drivers, improve traffic safety and have a positive impact on the environment (less fuel used and lower $\mathrm{CO}_{2}$ emissions) [31].

Recently, Czestochowa has established cooperation with InPost as part of the "Green City" project supporting the development of Polish cities in accordance with the idea of "smart city". Inhabitants of Czestochowa will have access to a number of modern city services that support the improvement of air quality and climate protection at the same time. Implementation and promotion of pro-ecological projects include reducing emissions of $\mathrm{CO}_{2}$, electric transport, and creating friendly and attractive public spaces for residents [32].

\section{Research Methodology}

The purpose of the conducted research was to determine the awareness of the inhabitants of polish cities of the smart city concept, and to elicit their expectations and experiences related to the implemented projects.

The research was conducted between February and June 2021 among inhabitants of the polish cities where smart cities projects were implemented. The questionnaire consisted of 13 questions, of which the first three were about the gender, age, and education of the respondent. Other questions were related to smart city projects implemented in their place of residence. The survey had the form of an anonymous one-topic consumer opinion poll.

It was a one-off survey. The questionnaire was on paper (it was handed over to fill by the respondents) or a document sent to respondents via email. The respondents were asked to pass the questionnaire to their friends so that as many people as possible could express their opinion. Due to the subject of the survey, a short explanation of the idea of smart cities was attached to each questionnaire, so that even those surveyed who earlier were not familiar with the idea of smart cities could easily answer the survey questions.

Twelve survey questions were closed questions, one of them was an open question. Eleven of them were of single choice and two questions were of multiple choice (one up to 3 answers, and one up to 2 answers). Ninety-six percent of received questionaries were filled out correctly.

\section{Results}

The tested group consisted of $n=396$ people ( 167 women and 229 men) between the ages of 18 and over 45 . As far as education is concerned, 72 percent (286 of respondents) declared that they have a university degree, 20 percent of the surveyed people have vocational education, 8 percent have secondary education, and one person has basic education. When asked about the socio-professional category, 79 percent of respondents declared that they are employed, 18 percent are entrepreneurs, and 3 percent (12 people) are unemployed.

The next question is about the size of the respondents place of residence.

As is apparent from Figure 1, 47 percent of respondents indicated that they live in a city with 100,000 to 300,000 inhabitants, as much as 27 percent declared that they live in a city with over 500,000 , and 2 percent of respondents have no knowledge of how many inhabitants live in their city of residence.

The next questions refer to the respondents' awareness of the idea of smart cities, and their experiences regarding this concept.

Another survey question refers to smart projects implemented in the city of residence of the person completing the survey.

When answering the question, for which responses are illustrated in Figure 2, 47 percent of respondents replied that smart cities projects were implemented in their cities of residence, while 38 percent of people who completed the questionnaire replied, that they did not know about it, and 9 percent of respondents believe that no smart projects are being implemented in their cities. 


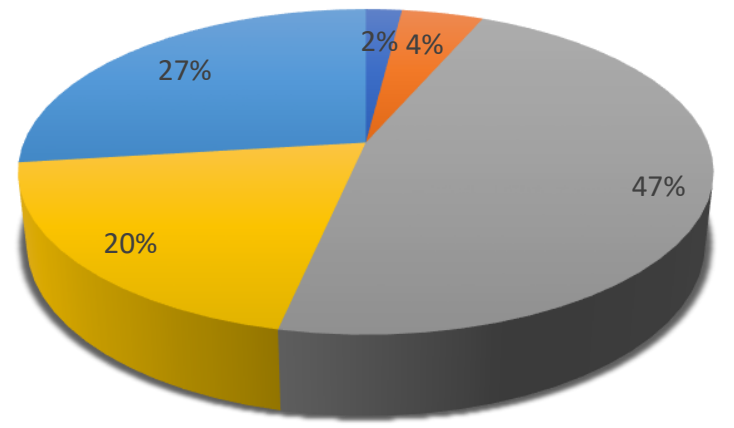

I do not know

The city with 100,000 to 300,000 inhabitants

The city with over 500,000 inhabitants
The city with up to 100,000 inhabitants

The city with 300,000 to 500,000 inhabitants

Figure 1. The size of your city of residence.

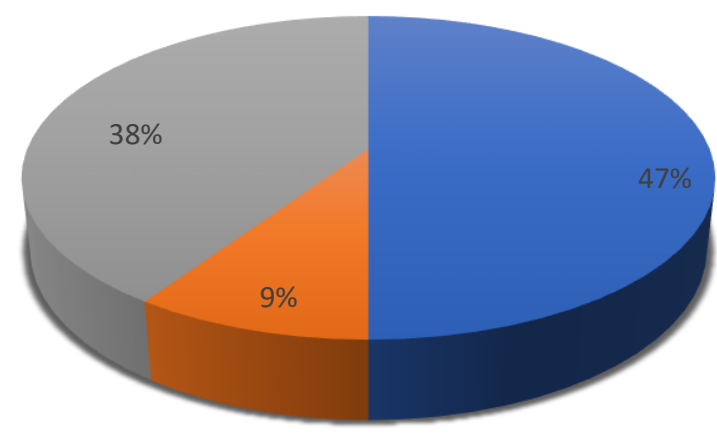

a yes no l do not know

Figure 2. Are smart projects implemented in your city of residence?

As noted in the description of the research conducted, the short description of the concept of smart cities was attached to the questionnaire, so that all respondents, even those who had not encountered this terminology before, could express their opinion.

The next question of the survey concerned how city residents understand the idea of smart cities. This question was an open question, and respondents were asked to briefly characterize the concept from their point of view. Among the most frequently given answers were modernity, innovation, self-sufficiency, covid pandemic amenities, attractiveness for residents, good air quality, energy obtained from renewable energy sources, taking care of the environment, the city that knows how to use information technologies to make life better for its inhabitants.

The next question was about the most important areas of implementation of smart cities projects.

When answering the question, the responses for which are illustrated in Figure 3, respondents had the opportunity to choose up to 3 answers. The most popular areas according to people participating in the study were security (26 percent of answers), healthcare, and sustainable transport with as many as 44 percent of the given answers. Other often mentioned areas were water, sewage and sanitation along with innovations (both 9 percent of answers given). Two percent of respondents had no opinion on the subject and 3 percent of them chose the answer "other". Asked which other areas they considered significant, they mentioned: science, telecommunications, online services, local connections, housing, cooperation with cultural and sports institutions and many services and discounts in one place. 


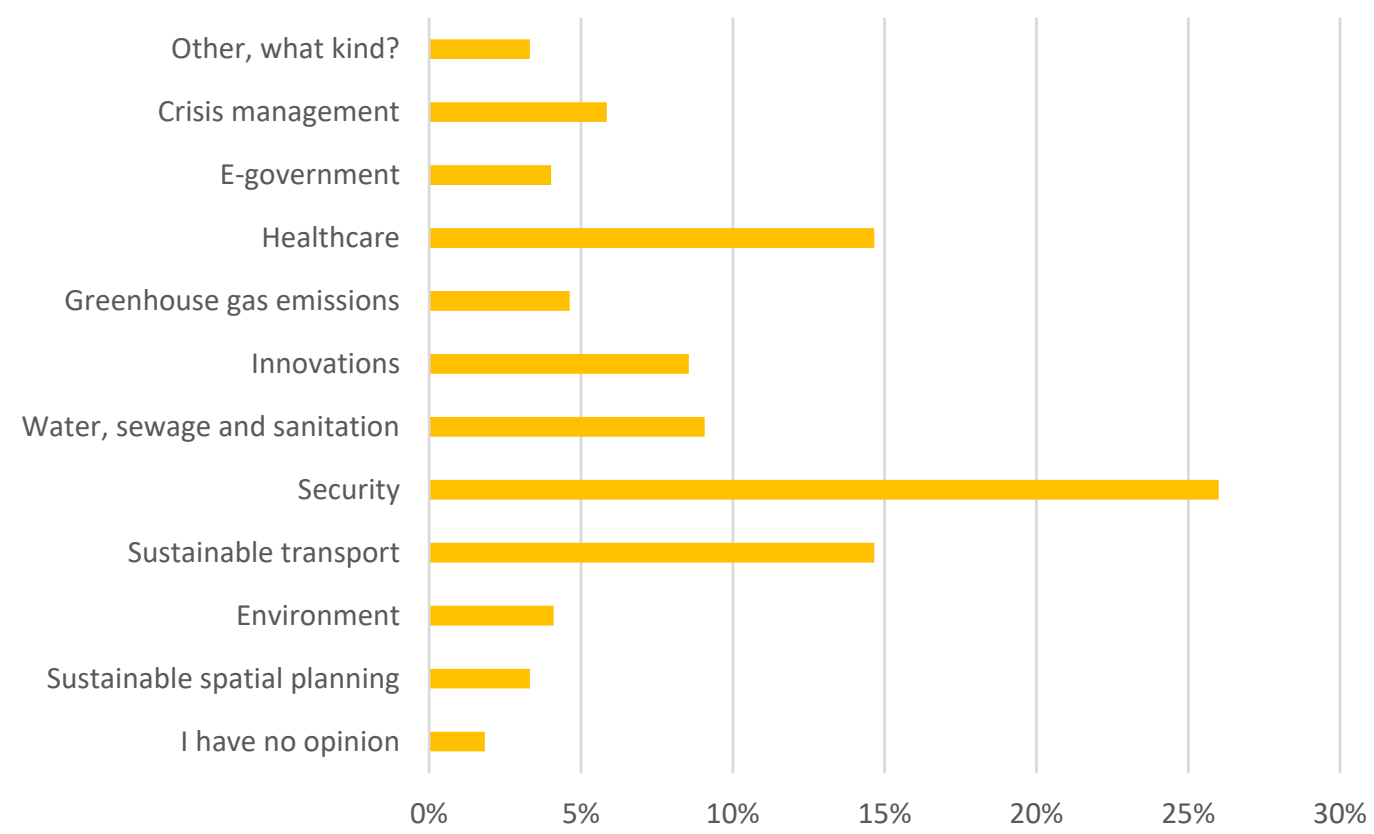

Figure 3. What areas, in your opinion, should be a priority when implementing measures in the field of smart cities?

The following question concerns whether respondents receive information about the city's smart activities.

As seen in Figure 4, which, in the author's opinion, is somewhat surprising, most of the respondents are of the opinion that the city does not provide enough information about the activities undertaken in the field of smart projects. This may be the result of the fact that respondents do not follow the news or do not know where to look for this information.

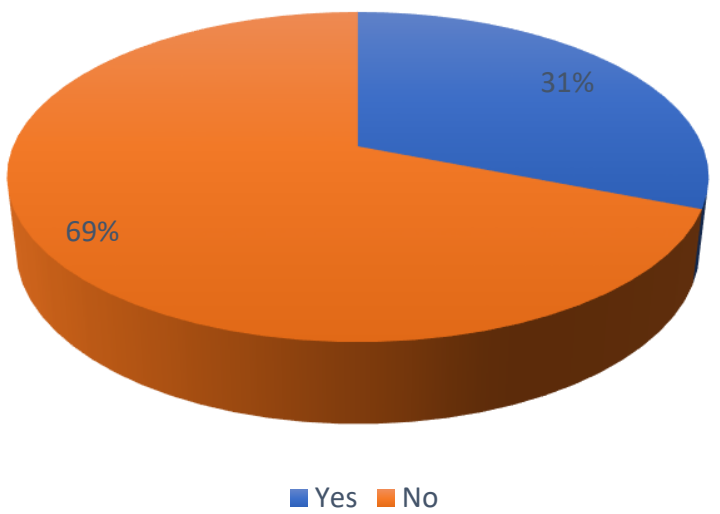

Figure 4. Do you think that the city adequately informs about actions taken in the area of smart?

The next question of the survey concerned the impact that a smart city related to ICT can have on saving electricity in cities.

When answering the question, the responses to which are illustrated in Figure 5, 47 percent of respondents believe that modern ICT technologies used in smart cities can have an impact on electricity savings. 40 percent of respondents do not have an opinion on this subject, while $13 \%$ of people believe that ICT has no impact on electricity savings in cities.

The following question concerns the area of the city's functioning where it is possible to achieve savings in electricity.

As is apparent from Figure 6, the most popular answer chosen by the respondents was "limitations resulting from the optimization of urban transport" - such an answer was chosen by as many as $44 \%$ of them. Another important area in which, according to the 
respondents, it is possible to achieve savings in electricity consumption is "urban lighting" (32 percent of answers).

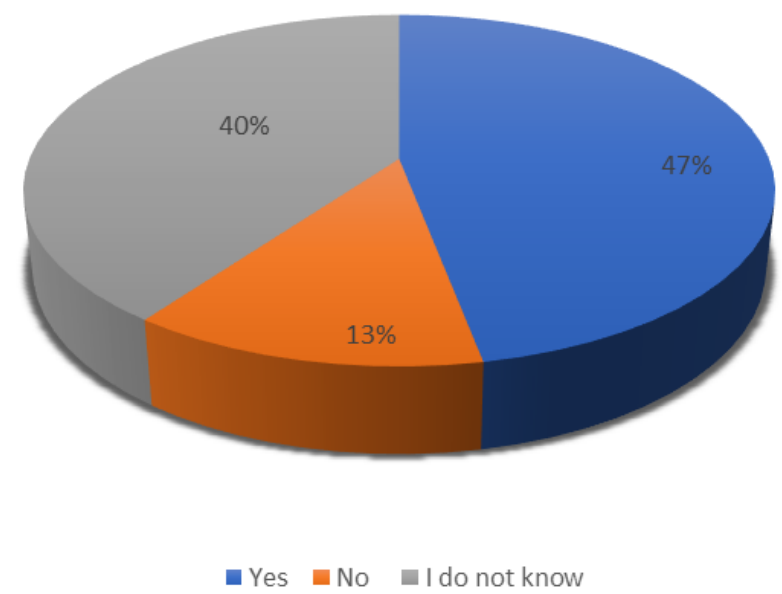

Figure 5. Do you think that smart city related to ICT can have an impact on saving electricity in cities?

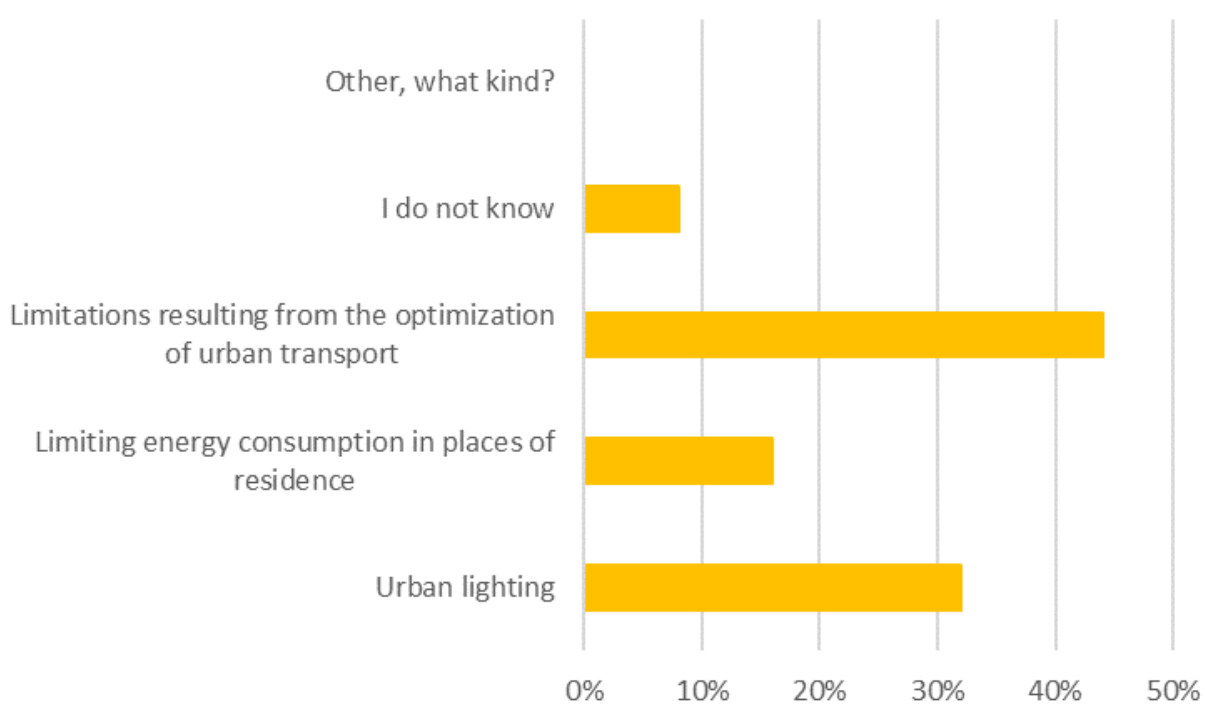

Figure 6. In what area of the city's functioning is it possible to achieve savings in electricity consumption as a result of the introduction and application of the smart city ideology?

The further question of the survey was about the impact of ICT technologies on the functioning of the smart city.

When answering the question, the responses to which are illustrated in Figure 7, as many as 61 percent of respondents believed that the use of modern ICT technologies in cities has a positive impact on their functioning. Twenty-two percent of people who took part in the survey do not have an opinion or do not know, while 17 percent of respondents believe that ICT related to the smart city has no positive effect on the functioning of the city.

The next, penultimate, question in the survey, concerns whether respondents would be willing to use technology to reduce electricity consumption if their standard of living did not deteriorate.

As seen from Figure 8, the vast majority, as much as 83 percent, declared that they would be in favor of using the technology if it would reduce electricity consumption. Seventeen percent of respondents had no opinion on this subject, and no one declared that they would not be in favor of such a technological solution. 


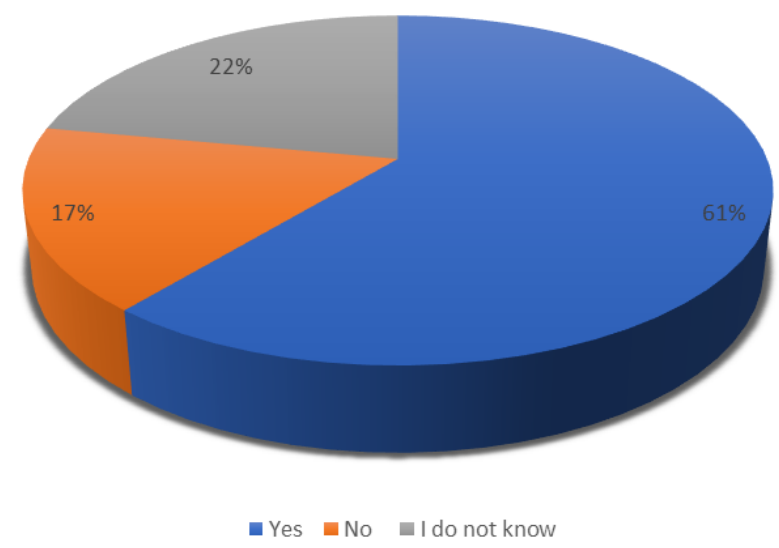

Figure 7. Do ICT technologies related to the smart city idea have a positive impact on the functioning of the city, including improving the lives of its inhabitants?

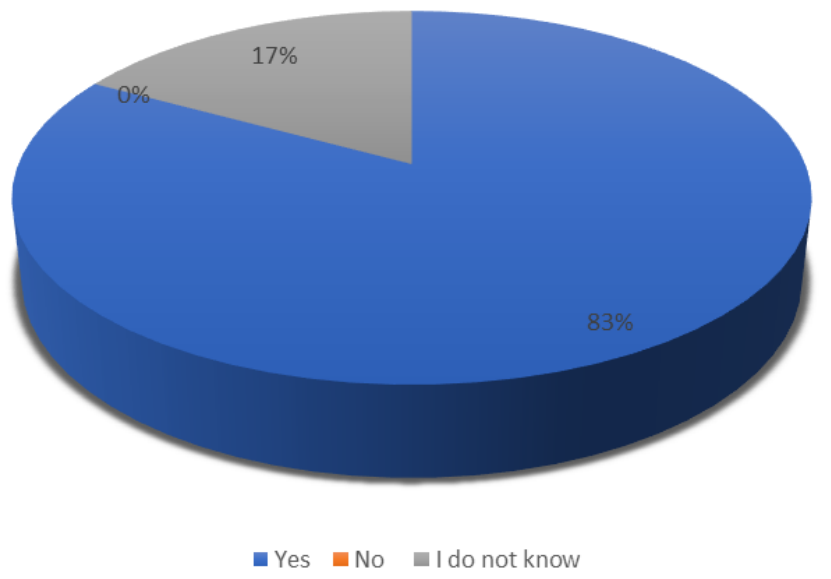

Figure 8. With the right technical measures at your disposal and assuming that your standard of living would not deteriorate, would you be in favor of using technology to reduce electricity consumption?

The last question of the survey concerned ICT solutions that are used in everyday life and help to reduce electricity consumption.

When answering the question, the responses to which are illustrated in Figure 9, respondents had the opportunity to choose up to two answers. They could also provide their own answer if it was not included in the one proposed by the author. The most frequently chosen answers were activation of lighting due to the occurrence of appropriate initiating factors $(30 \%)$ and LCD displays (28\%).

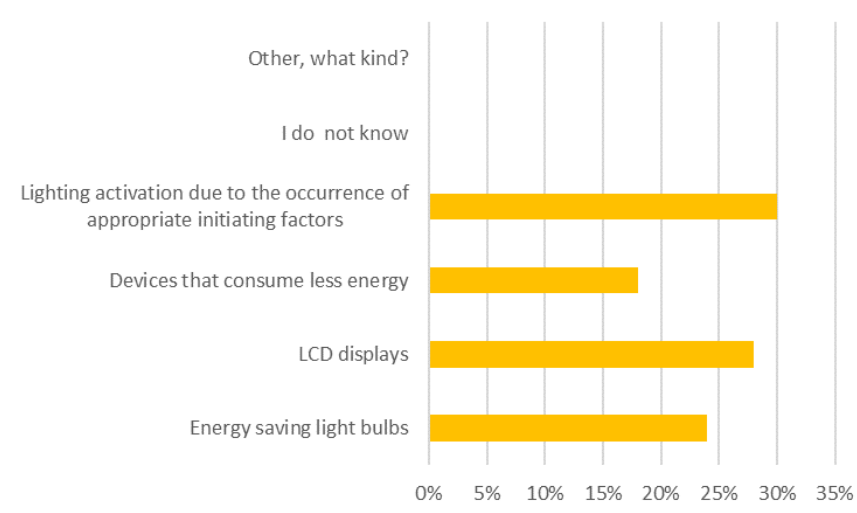

Figure 9. What ICT solutions used in everyday life are used to reduce electricity consumption? 
The conducted research shows that despite the fact that the awareness of the smart city idea is small or not very large, most respondents believe that ICT is useful-which results from human experiences in everyday life. At the same time, these applications in the scale of public utility, i.e., residents, are little known and little used in our country.

\section{Conclusions}

The smart idea has grown in importance in recent years. Everything around us is smart. We use smartphones, smart watches, our cars are intelligent. By its simplest definition, a smart city is a city that uses modern technologies to improve the lives of its inhabitants and urban infrastructure. Polish cities are already reaching for intelligent transport systems, traffic management or monitoring of electricity consumption or the level of pollution. Unfortunately, many of these activities are called single shots. Cities implement selective projects without thinking about long-term activities, systematic changes, and orderly development of the city. These single actions have enormous potential to bring solutions to the most pressing problems such as traffic jams, public transport, or smog.

Despite the numerous benefits that result from implementing smart solutions, many cities still cannot afford such investments. Not only are financial considerations important here. Research has shown that as much as 68 percent of cities show a lack of technological knowledge to build digital platforms. Also, the technological awareness of officials is not at such an advanced level as to be able to initiate and implement modern solutions. Data issues are a big challenge. Rich, complete data together with advanced analytics may allow cities to use the potential of technology, but it raises great social concerns about privacy $(63 \%)$. Forty-three percent of officials also point to the huge gaps in IT infrastructure in data management by the city and 39 percent lack funds for such investments [33].

The most intelligent cities in the world include Singapore, New York, Toronto, and Canberra. The leading places in the ranking of European cities are taken by Amsterdam, Copenhagen, Helsinki, Stockholm, and London [33]. These are cities where the vision of intelligent development has been realized, both in strategic and tactical terms. Among Polish smart cities, one should mention, among others, Warsaw, Kraków, Wrocław, Białystok, and Gdańsk.

According to the questionnaire survey conducted for the purposes of this article, smart city projects are implemented in large and very large Polish cities, which means that municipalities have noticed the positive role of developing digital infrastructure and want to provide residents with the best possible living conditions, ensuring their comfort and convenience. The most popular areas of implementation of smart cities projects according to respondents were security, healthcare, sustainable transport, water, sewage, and sanitation along with innovations. The respondents showed great interest in the subject of the survey, and willingly provided additional comments to questions that were not required, while most of them pointed out that the information on the smart cities projects did not reach them. As mentioned earlier this may be the result of the fact that information on initiatives related to smart cities may not be sufficiently publicized, or respondents do not know where to look for it. The respondents' answers allow us to conclude that the first hypothesis adopted in the paper has been verified as true. According to the author, the lack of knowledge about the essence and usefulness of smart ideology is related to insufficient publicity for proposals and projects introduced by cities, as well as the fact that residents do not know where to look for information about them.

Based on the research, it was found that a smart city related to ICT technologies can have an impact on electricity savings in cities. Moreover, achieving savings in electricity consumption as a result of the introduction and application of the smart city ideology, according to the respondents, is particularly possible through limitations resulting from the optimization of urban transport and in the area of urban lightning. Sixty-one percent of respondents believe that ICT technologies related to the smart city idea have a positive impact on the functioning of the city. Almost every surveyed person declared that, having the appropriate technical means at their disposal, they would be in favor of using the 
technology to reduce electricity consumption (as long as their standard of living would not be lower). The research results indicated that the respondents are aware that the solutions used in everyday life are used to reduce electricity consumption. On this basis, it is possible to confirm the truth of the second hypothesis - the idea of smart city has a positive impact on the issues of electricity consumption savings in modern cities.

The research limitations faced by the author of the publication are related to the limited access to city residents. Another limitation is the limited knowledge of residents about the essence and possibilities of a smart city. At the same time, it should be pointed out that the undertaken subject covers a very important area of human functioning. The constant consumption of energy sources, with the increasing population, forces us to take actions that will allow us to obtain energy from new sources, and at the same time reduce its consumption to the necessary minimum. This requires, on the one hand, the use of modern technological solutions, and on the other hand, their conscious use. All this makes it necessary to further consider the issues raised in the publication.

Due to the limited nature of the text in the publication, the issues raised have been analyzed only to a limited extent. Subsequent analyses may be related to the impact of ICT awareness and awareness of limiting electricity consumption on an individual basis. They should also include the possibility of using the smart city idea in the largest possible area of human functioning, which is undoubtedly associated with raising awareness of the importance of such an approach. Another proposed research area is the ability and possibility to limit the number of devices that consume electricity and are part of urban equipment, including advertising measures, such as whether there are there such expectations, and, if so, under what conditions and circumstances, etc.

Funding: This research received no external funding.

Institutional Review Board Statement: Not applicable.

Informed Consent Statement: Informed consent was obtained from all subjects involved in the study.

Data Availability Statement: Not applicable.

Conflicts of Interest: The author declares no conflict of interest.

\section{References}

1. PropertyDesign.pl. The Transformation of Cities into Smart Cities Is Accelerating Due to the Pandemic. Available online: https:/ / www.propertydesign.pl/architektura/104/transformacja_miast_w_smart_cities_przyspiesza_za_sprawa_pandemii, 30838.html (accessed on 20 June 2021).

2. Standard ISO 37120:2014. In Sustainable Development of Communities-Indicators for City Services and Quality of Life-DS./ISO 37120, 1st ed.; International Organization for Standardization: Geneva, Switzerland, 2014.

3. Yeh, H. The effects of successful ICT-based smart city services: From citizens' perspectives. Gov. Inf. Q. 2017, 34, 556-565. [CrossRef]

4. Hoffman, I.M.; Goldman, C.A.; Rybka, G.; Leventis, G.; Schwartz, L.; Sanstad, A.H.; Schiller, S. Estimating the cost of saving electricity through U.S. utility customer-funded energy efficiency programs. Energy Policy 2017, 104, 1-12. [CrossRef]

5. How Smart City Technologies Improve the Quality of Life. Available online: https://www.copadata.com/pl/przemyslowa/ inteligentne-miasto/smart-city-insights/jak-technologie-smart-city-poprawiaja-jakosc-zycia-copa-data/ (accessed on 12 June 2021).

6. Smart City-Solutions for Institutions. Buildings and Transport in Smart Cities. Available online: https://www.copadata.com/ $\mathrm{pl} /$ przemyslowa/inteligentne-miasto/ (accessed on 11 July 2021).

7. Martínez, L.; Short, J.R. The Pandemic City: Urban Issues in the Time of COVID-19. Sustainability 2021, 13, 3295. [CrossRef]

8. Hasija, S. Smart Cities Can Help Us Manage Post-COVID Life, but They'll Need Trust as Well as Tech. The Conversation. Available online: https:/ / theconversation.com/smart-cities-can-help-us-manage-post-covid-life-but-theyll-need-trust-as-wellas-tech-138725 (accessed on 13 June 2021).

9. Tosiek, D. Social Safety Management in Smart City; AGH: Kraków, Poland, 2017.

10. Public Transport Security in the Smart City Era, Challenges and Solutions for European Bus, Metro and Rail Companies, Make the World See. 2020. Available online: https:/ / aspolska.pl/bezpieczenstwo-transportu-publicznego-w-erze-smart-city/ (accessed on 24 April 2021). 
11. Appelboom, G.; Camacho, E.; Abraham, M.E.; Bruce, S.S.; Dumont, E.L.P.; Zacharia, B.E.; D'Amico, R.; Slomian, J.; Reginster, J.Y.; Bruyere, O.; et al. Smart Wearable Body Sensors for Patient Self-Assessement and Monitoring. Arch. Public Health 2014, 72, 1-9. Available online: http:/ /www.archpublichealth.com/con-tent/72/1/28 (accessed on 17 May 2021). [CrossRef]

12. Chan, B. Smart Cities \& Public Health Emergency Collaboration Framework. Meeting of the Minds. Available online: https: //meetingoftheminds.org/smart-cities-public-health-emergency-collaboration-framework-33446 (accessed on 12 April 2021).

13. Michalak, B.; Karlińska, M.; Glinkowski, W. The Potential of New e-Health Services for Residents of Smart Cities in Light of the Current Legal Situation. Available online: http://rocznikikae.sgh.waw.pl/p/roczniki_kae_z42_21.pdf (accessed on 18 April 2021).

14. Smart City: How Smart Cities Improve People's Lives. Available online: https://ideologia.pl/smart-city-jak-inteligentne-miastapoprawiaja-zycie-mieszkancow/ (accessed on 10 May 2021).

15. GUS (Central Statistical Office). Population. Condition and Structure in a Territorial Profile; As of 30.VI.2017 r; Central Statistical Office: Warszawa, Poland, 2017.

16. Bibri, S.E.; Krogstie, J. Smart Sustainable Cities of the Future: An Extensive Interdisciplinary Literature Review. Sustain. Cities Soc. 2017, 31, 183-212. [CrossRef]

17. Capgemini Research Institute. Street Smart. Putting the Citizen at the Center of Smart City Initiatives. Available online: https:/ / www.capgemini.com/wp-content/uploads/2020/07/Street_Smart_28-07-2020_SS.pdf (accessed on 20 June 2021).

18. CNBC. Two-Thirds of Global Population Will Live in Cities by 2050. UN Says, 15 May 2018.

19. Track MPK Vehicles on Your Phone-New Application. Available online: https://www.wroclaw.pl/sledz-pojazdy-mpk-natelefonie (accessed on 12 May 2021).

20. The Model Housing Estate Nowe Żerniki in Wrocław Fulfills the Vision of the City of the Future Thanks to the Lighting of Philips Lighting. Available online: https:/ / www.signify.com/pl-pl/our-company/news/press-release-archive/2017/20171031-thenowe-zerniki-housing-estate-in-wroclaw-is-making-the-vision-of-the-city-of-the-future-come-true-with-the-use-of-philipslighting (accessed on 12 May 2021).

21. Virtual Advisor to a Resident at the City Hall. Available online: https:/ / www.wroclaw.pl/wirtualny-doradca-mieszkanca-urzadmiejski-wroclaw (accessed on 21 June 2021).

22. Knight Frank. Wrocław towards Smart City. Available online: https:// content.knightfrank.com/research/1613/documents/pl/ wroclaw-w-kierunku-smart-city-2018-5862.pdf (accessed on 18 April 2021).

23. PropertyDesign.pl. Lublin: A Dynamically Developing Smart City in Eastern Poland. Available online: https://www. propertydesign.pl/architektura/104/lublin_preznie_rozwijajace_sie_smart_city_w_polsce_wschodniej,28264.html (accessed on 20 June 2021).

24. Lublin-A City of Inspiration, Lublin with the Smart City Award. Available online: https://lublin.eu/biznes-i-nauka/skrotsubserwisu-strona-glowna/lublin-z-nagroda-smart-city-award,1043,791,1.html (accessed on 20 June 2021).

25. Union of Polish Metropolises. Lublin Is an Intelligent City. Available online: https://metropolie.pl/artykul/lublin-jest-miasteminteligentnym (accessed on 12 May 2021).

26. Lublin City of Inspiration. Project "Development and Implementation of an Integrated IT System for Educational Units of the City of Lublin". Available online: https:/ /lublin.eu/edu/projekt/o-projekcie/ (accessed on 12 May 2021).

27. Gołuchowski, J.; Korzeb, M.; Weichbroth, P. The participation of economic entities as a determinant of the transformation of a modern city towards an intelligent city. Economic Studies. Sci. J. Univ. Econ. Katow. 2015, 243, 119-150.

28. Lublin a City of Inspiration. Together We Create the Lublin 2030 Strategy. Available online: https://lublin.eu/lublin/aktualnosci/ wspolnie-tworzymy-strategie-lublin-2030,9260,66,1.html (accessed on 13 May 2021).

29. Local Government Loyalty Program. Available online: karta.czest.pl (accessed on 13 May 2021).

30. Częstochowa City Bike. Available online: https://rower.czestochowa.pl/ (accessed on 14 May 2021).

31. Czestochowa Counters at the Traffic Lights. Available online: https://naszemiasto.pl/tag/czestochowa-liczniki-na-swiatlach (accessed on 17 May 2021).

32. Program Green City. Available online: https:/ / dziennikzachodni.pl/czestochowa-dolacza-do-programu-green-city-w-urzedziemiasta-podpisano-list-intencyjny/ar/c1-15677864 (accessed on 12 May 2021).

33. Giffinger, R.; Fertner, C.; Kramar, H.; Kalasek, R.; Pichler-Milanovic, N.; Meijers, E.I. Smart Cities. Ranking of European Mediumsized Cities. TU Wien, University of Ljubljana, TU Delft. Available online: http://www.smart-cities.eu/download/smart_cities_ final_report.pdf (accessed on 20 June 2021). 